\title{
EXPLORING THE DEEP: LOOKING FOR DEEP LEGAL PLURALISM IN THE SOUTH PACIFIC
}

\author{
Jennifer Corrin*
}

Over the past 40 years, the concept of legal pluralism has gradually gained broader recognition. However, the depth of this pluralism, in the sense of the degree of recognition given to non-state systems of law, varies dramatically from place to place. This article looks at legal pluralism in South Pacific. Commencing with a brief explanation of the different ways in which legal pluralism can be conceptualised, it gives a general overview of the way in which it is manifested in South Pacific legal systems. Selected South Pacific statutes that acknowledge customary laws or institutions are then examined to assess whether this equates with deep legal pluralism, or whether, in reality, it amounts only to state legal pluralism.

\section{INTRODUCTION}

Legal pluralism is usually taken to refer to a situation in which two or more legal orders coexist in the same social field. Over the past 40 years, the concept has gradually gained broader recognition. It is now widely acknowledged that it is not restricted to developing countries and nor is it a recent phenomenon. ${ }^{1}$ However, the depth of this pluralism, in the sense of the degree of recognition given to non-state systems of law, varies dramatically from place to place. Recognition by the state spans from mere acceptance as fact (which does not constitute legal pluralism), ${ }^{2}$ across a broad spectrum of recognition within the state system (which may be classified as state legal pluralism), to

* Professor Jennifer Corrin is Executive Director, Comparative Law, Centre for Public, International and Comparative Law, TC Beirne School of Law, The University of Queensland. The author would like to acknowledge the contribution of Professor Sue Farran to the section on the Custom Land Management Act, which benefits from previous joint research and Professor Farran's empirical work.

1 Brian Z Tamanaha "Understanding Legal Pluralism: Past to Present, Local to Global" (2008) 30 Sydney Law Review 375 .

2 Bradford W Morse and Gordon R Woodman "Introductory Essay: The State's Options" in Bradford W Morse and Gordon R Woodman (eds) Indigenous Law and the State (Foris, Dordrecht, 1988) 5 at 10-11. 
acknowledgement of the capacity of non-state institutions to make laws or to apply them (which may be classified as deep legal pluralism).

This article commences with a brief discussion of legal pluralism and the different ways in which it can be conceptualised. It then moves on to consider how legal pluralism is manifested in South Pacific legal systems. After a general overview of the systems put in place by Pacific constitutions, the article proceeds to consider some examples of legislation passed by South Pacific countries that acknowledges the capacity of customary institutions for law-making, application of the law, or both. These statutes are sometimes heralded as an indication of the state's strong commitment to accommodation of legal pluralism. Through an analysis of the selected statutes, the article seeks to determine whether the semblance of deep legal pluralism withstands scrutiny, or whether recognition, in reality, constitutes only state legal pluralism.

\section{STATE LEGAL PLURALISM VERSUS DEEP LEGAL PLURALISM}

Legal pluralism is a contested concept, perhaps due to the fact that it is employed by scholars from a variety of disciplines, including law, anthropology and other social sciences. As mentioned, it has been described as referring to a situation in which two or more legal orders coexist in the same social field. ${ }^{3}$ More recently, it has been reconceptualised by some scholars as a species of normative pluralism, avoiding the issue of whether non-state law qualifies as legal. According to this view, legal pluralism is a situation where coexisting sets or orders of norms are regarded as legal by actors in the context of the social field in question. ${ }^{4}$ Normative pluralism is not just a matter of observation of the existence of more than one legal order as a social fact; it allows reflection on all norms observed in a community and consideration of the legitimacy of an order, either within the community or by those outside it.

Whichever of these definitions is employed, there is a further distinction to be made between "weak" or "state" pluralism on the one hand, and "deep" or "strong" pluralism on the other. Again, there are differing definitions of these categories. In basic terms, the former, which will be referred to in this article as "state" legal pluralism, refers to the coexistence of two or more bodies of norms that are recognised by the state, but with the proviso that the state is the source of authority for all laws. The latter, which will be referred to as "deep" legal pluralism, refers to the coexistence of legal orders with different sources of authority. Deep legal pluralism may arise from acknowledgement by the state that it does not have a monopoly to make laws or, more rarely, from an acknowledgment that it does not have the sole power to apply them.

3 Sally Engle Merry "Legal Pluralism" (1988) 22 L \& Socy Rev 869 at 870.

4 Tamanaha, above n 1, at 396; and William Twining "Legal Pluralism 101" in Brian Tamanaha, Caroline Sage and Michael Woolcock (eds) Legal Pluralism and Development: Scholars and Practitioners in Dialogue (Cambridge University Press, Cambridge, 2012) 112 at 114-115. 
It has been argued that only deep pluralism is "real" legal pluralism and that state legal pluralism is a legacy of colonialism. ${ }^{5}$ This argument is based on the view that state pluralism, whilst recognising the existence of other laws, leaves the state with the power to determine the role that semi-autonomous bodies will play. ${ }^{6}$ This, it is said, supports the ideology of legal centralism as it fails to step away from the idea that all forms of law rely on state recognition for their validity. ${ }^{7}$ However, this view is contested, particularly by legal scholars who regard recognition and application of other laws by the state as an important type of legal pluralism. ${ }^{8}$ Certainly, the state often relegates non-state law and the surrounding institutions to an inferior position, placing them at the bottom of the hierarchy in respect of both the making of law and its application. ${ }^{9}$ However, this does not exclude them from playing a more important role outside of the state hierarchy. Further, a binary distinction between state and deep legal pluralism is problematic. As illustrated by the analysis in this article, the line between state and non-state laws and institutions is often blurred. Further, the relationship between the state and nonstate institutions is not static, and authority and control are often a question of degree.

\section{PLURAL LEGAL SYSTEMS IN THE PACIFIC}

Political developments in the 1960s and 1970s saw the majority of South Pacific countries emerge as sovereign states. The preambles to the independence constitutions generally reflected a desire for laws encapsulating local values and objectives to be respected. For example, the Constitution of Solomon Islands began with an aspirational declaration of pride in "the wisdom and the worthy customs" of Solomon Islanders' ancestors and a pledge to "cherish and promote the different cultural traditions within Solomon Islands". ${ }^{10}$ In most countries, this rhetoric was given some substance by the recognition of customary law as part of state law. However, the balance of the state legal system was based on the common law model, ${ }^{11}$ with the constitution as the supreme law. ${ }^{12}$ Parliament was to make laws for "peace, order and good government". ${ }^{13}$ As a transitional measure, to fill the void

5 See for example Eve Darian-Smith and Peter Fitzpatrick (eds) Laws of the Postcolonial (University of Michigan Press, Ann Arbor, 1999).

6 John Griffiths "What is legal pluralism?" (1986) 24 J Legal Plur 1 at 8.

7 At 8 .

8 Gordon Woodman "Ideological Combat and Social Observation: Recent Debate about Legal Pluralism" (1998) 42 J Legal Plur 21; and Yuksel Sezgin "Theorizing Formal Pluralism: Quantification of Legal Pluralism for Spatio - Temporal Analysis" (2004) 50 J Legal Plur 101 at 101-103.

9 See for example Constitution of the Republic of Vanuatu 1980, art 1 as interpreted in Banga $v$ Waiwo SC Vanuatu Appeal Case No 1 of 1996, 17 June 1996 at 9.

10 Constitution of Solomon Islands 1978, preamble.

11 The exception is Vanuatu, which adopted both a civil and common law system.

12 See for example the Constitution of Solomon Islands 1978, s 2.

13 Section 59(1). 
until they were replaced by locally enacted laws, colonial laws ${ }^{14}$ and received legislation, in force prior to independence, were "saved". ${ }^{15}$ English common law and equity up to a specified date also remained in force, to be utilised and developed by domestic courts through the doctrine of precedent. ${ }^{16}$

These arrangements resulted in plural legal systems. However, the extent and depth of this pluralism, or, in some instances, whether it amounts to pluralism at all, ${ }^{17}$ is a matter of contention. Pacific states have tended to incorporate customary laws into the state system by reference, providing that they are a source of law to be applied by state courts. ${ }^{18}$ In addition, as mentioned above, customary laws are usually allotted an inferior status in the hierarchy laid out by the constitution. ${ }^{19}$ This results in a tendency to assume the supremacy of the common law. ${ }^{20}$ As Benton points out, such an approach to legal pluralism brings with it "a sense of inevitability about the dominance of state law". ${ }^{21}$ Further, and importantly, even where state law assigns a major role to customary laws in the state system, this mandate is, in practice, often ignored by the courts. ${ }^{22}$ However, whilst incorporation by reference amounts primarily to state legal pluralism, it does carry with it an implicit acknowledgment of the power of customary institutions to make law, which could be said to constitute deep legal pluralism. ${ }^{23}$ The power of customary institutions to apply that law is, however, rarely acknowledged. Rather, this task is usually left to state courts, which have had a tendency to try to mould it to the shape of more familiar concepts, and to expect it to comply with the adjectival demands of the common law system. ${ }^{24}$

14 Colonial laws were made locally or enacted by the coloniser especially for its colonies, protectorates or dependencies, such as the Western Pacific (Courts) Order in Council 1961 (UK).

15 See for example the Constitution of Solomon Islands 1978, s 76.

16 See further Cheung $v$ Tanda [1984] SILR 193 (CA).

17 Griffiths, above n 6, at 8. For an alternative view, see Baudouin Dupret "Legal pluralism, plurality of laws, and legal practices: Theories, critiques, and praxiological re-specification" (2007) 1 EJLS 296.

18 See for example Customs and Adopted Laws Act 1971 (Nauru), s 3; and Constitution of the Independent State of Samoa 1960, art 111(1).

19 See for example Constitution of Vanuatu 1980, arts 2, 47(1) and 95, as interpreted in Banga v Waiwo, above n 9.

20 See further Jennifer Corrin "Moving Beyond the Hierarchical Approach to Legal Pluralism in the South Pacific" (2009) 59 J Legal Plur 29.

21 Lauren Benton Law and Colonial Cultures: Legal Regimes in World History, 1400-1900 (Cambridge University Press, Cambridge, 2002) at 9.

22 See for example Sasango v Beliga [1987] SILR 91 (Magistrates Court).

23 Morse and Woodman, above n 2, at 17.

24 Jennifer Corrin "Round Pegs and Square Holes: Pleading indigenous customary laws in Australia and the South Pacific" (2014) 33 CJQ 475. 


\section{POSSIBLE EXAMPLES OF DEEP LEGAL PLURALISM?}

As mentioned above, deep legal pluralism may arise from acknowledgement that non-state institutions have the power to make laws, or that they have the power to apply them, for example, in the exercise of adjudicatory powers. The first part of this section examines a legislative attempt to recognise laws made by customary authorities and considers whether this constitutes deep legal pluralism of the first type. The second part looks at local innovations, designed to recognise the role of customary institutions in dispute resolution, and thus potentially providing a rare example of the second type of acknowledgement. ${ }^{25}$ Constitutional arrangements and legislation generally provide for customary laws to be administered in courts or other fora established by legislation, rather than by customary institutions. As noted by Morse and Woodman, such fora fall short of deep legal pluralism, as "acknowledgement does not occur when state law establishes an institution, even one which resembles a former customary law institution". ${ }^{26}$ The last part of this section examines two instances where the state has recognised both types of power, acknowledging the power of customary institutions to make and to adjudicate on customary laws.

\section{A Law-Making Powers}

At independence, Papua New Guinea went further than any other regional country in trying to give customary laws a prominent place in the country's legal system. ${ }^{27}$ The Constitution provided that "custom is adopted, and shall be applied and enforced, as part of the underlying law". ${ }^{28}$ Shortly afterwards, the Law Reform Commission issued a report designed to put this provision into practice, accompanying it with a draft Bill. ${ }^{29}$ It took some 23 years for Papua New Guinea's Parliament to enact the Underlying Law Act 2000. Whilst undoubtedly having a common law foundation, the Act charted new territory. It provides that, if there is no provision of the written law (by which is meant the Constitution or a statute) ${ }^{30}$ governing the issues in dispute, ${ }^{31}$ the court must extract the underlying

25 See generally Morse and Woodman, above n 2, at 15 .

26 At 16

27 See further Jean Zorn and Jennifer Corrin "Everything Old is New Again: The Underlying Law Act of Papua New Guinea" [2002] Lawasia Journal 61 at 64.

28 Constitution of the Independent State of Papua New Guinea 1975, sch 2.1(1).

29 Law Reform Commission of Papua New Guinea The Role of Customary Law in the Legal System (Report No 7,1977 ) at 20. This was the second draft Bill produced by the Law Reform Commission.

30 Underlying Law Act 2000 (PNG), s 1(1); and Constitution of the Independent State of Papua New Guinea, s 9 .

31 Underlying Law Act 2000 (PNG), s 6. 
law of Papua New Guinea primarily from customary laws, using common law as a secondary source if necessary. ${ }^{32}$

Apart from directions on how to formulate and develop the underlying law, the Act encourages the use of customary laws by:

- $\quad$ raising the status of customary laws from fact to law; 33

- broadening the scope of applicable customary laws beyond the "traditional" sphere, ${ }^{34}$

- providing a statutory presumption that custom will apply, and an equal presumption that the imported common law will not; ${ }^{35}$

- giving specific guidelines for the courts to ascertain the existence and content of customary laws; 36

- $\quad$ providing for resolution of conflicts between different customary laws $;^{37}$ and

- requiring reasons for refusing to apply a principle of customary law. ${ }^{38}$

Whilst the implied acknowledgment of the power of customary institutions to make law may amount to deep legal pluralism, and despite elevation of those laws to rank above the common law, the degree of recognition is more restricted than it would first appear. One serious encroachment on the application of customary laws under the Act is that, when being considered by a state court as a source of underlying law, they become subject to the demands of the adversarial system. Whilst the Act states clearly that customary laws are to be treated as law, not fact, ${ }^{39}$ it has been interpreted as requiring parties to plead customary laws before they can be relied on in court. ${ }^{40}$ The Act also requires parties and counsel to provide relevant evidence and information on customary laws and their applicability to the court to assist its formulation of the underlying law. ${ }^{41}$

32 Section 7

33 Section 11.

34 Section 7(2)(b).

35 Section 4(3).

36 Section 16(2).

37 Section 17

38 Section 4(4).

39 Section 16

40 New Britain Oil Palm Ltd v Sukuramu SC Papua New Guinea SCA 11 of 2007, 30 October 2008 at [18]. This requirement has now been inserted in court rules by the Rules of the National Court of Justice (Underlying Law Amendment) 2011 (PNG).

41 Underlying Law Act 2000 (PNG), ss 11 and 15. 
A further sign of the state's intrusion on customary laws, and evidence of the Act's common law foundation, can be found in its reliance on the doctrine of precedent, which binds courts to follow decisions on the underlying law of courts above them in the hierarchy, in the same way as they are obliged to follow common law precedents. ${ }^{42}$ This is linked to another limitation which lies in the fact that, once customary laws are encapsulated in the underlying law, the state appropriates the right to develop them, transferring this power from customary institutions to the courts. ${ }^{43}$ Where the Supreme Court or National Court considers "that a rule of the underlying law is no longer appropriate to the circumstances of the country", it may formulate a new rule of the underlying law. ${ }^{44}$ Whilst the new rule must also be drawn primarily from the customary laws, leaving the acknowledgment of the lawmaking power of customary institutions intact, it is the court which decides whether the old rule is inappropriate.

There are a number of other stumbling blocks presented by the Act, both in the form of the restrictions it places on the use of customary laws and the ambiguities within the Act which may be seized on by those seeking to avoid the application of customary laws. Areas of uncertainty which have hampered the courts include:

- the prohibition on formulating underlying law in areas involving policy issues;

- the question of whether the Customs Recognition Act has been repealed by the Underlying Law Act; ${ }^{45}$

- a drafting error in s 7(6), which may allow a party to contract out of customary laws even where this would cause injustice; and

- a drafting error in s 4(3), which may allow inappropriate common law to be applied.

Notwithstanding these problems and encroachments, as explained above, in requiring courts to apply customary laws, the law-making powers of customary institutions are implicitly accepted. For this reason, the Underlying Law Act seems to operate not only as a measure of incorporation, but also as a measure of acknowledgment, and to this limited extent could be said to constitute deep legal pluralism. However, given the common law trappings which accompany the application of customary laws under the Act, it seems more accurate to say that it creates a uniquely Papua New Guinean common law, rather than a deep legal pluralism.

42 Section 19. See New Britain Oil Palm Ltd v Sukuramu, above n 40.

43 Underlying Law Act 2000 (PNG), s 9.

44 Section 9.

45 In 21 ILGS Gobe Project Area Incorporated Land Groups v Imawe Bogasi ILG National Court of Papua New Guinea WS No 1027 of 2005, 29 September 2006, the National Court relied on the Customs Recognition Act as grounds for refusing to recognise a cause of action founded on customary law. See Jennifer Corrin "Getting Down to Business: Developing the Underlying Law in Papua New Guinea" (2014) 46 J Legal Plur 155. 


\section{B Power to Adjudicate}

As mentioned above, many countries of the region have chosen to establish "customary courts" by legislation, rather than acknowledging the power of customary institutions to adjudicate. The aim of establishing such courts is to provide a more flexible and informal forum for resolution of disputes. However, these courts are not traditional fora and in reality they are often adversarial, or at least overly formal, and do not resolve issues in a customary way. ${ }^{46}$ In a few notable cases, however, attempts have been made to recognise the authority of customary institutions to resolve disputes. These include adjudication by chiefs in Solomon Islands, and the degree to which these arrangements constitute examples of deep legal pluralism will now be analysed.

In Solomon Islands, so called "customary" courts have been set up in the form of Local Courts. These courts have jurisdiction to deal with minor disputes arising within the geographical area for which they are constituted, and exclusive jurisdiction to deal with all proceedings of a civil nature affecting, or arising in connection with, customary land. ${ }^{47}$ Whilst it is provided that these courts "shall be constituted in accordance with the law or customs of Islanders of the area in which the court is to have jurisdiction", 48 in practice, they are constituted in the manner specified by the Chief Justice in the warrant under which they are established. ${ }^{49}$ Having been established by legislation, these are state courts and the only sense in which they are customary is that they "administer the law and custom of Islanders prevailing in the area of the jurisdiction of the court". ${ }^{50}$ Even then, this is only "so far as the same has not been modified by any Act". ${ }^{51}$ As in the case of Papua New Guinea's courts under the Underlying Law Act, the fact that the Local Courts are obliged to administer the "law and custom of Islanders" carries with it an implicit recognition of the power of customary institutions to make customary laws and, to this limited extent, may be regarded as constituting deep legal pluralism. However, in this section, we are concerned with whether there has been an acknowledgment of the power of customary institutions to apply the law, as opposed to making it. As originally established, the Local Courts Act, whilst not prohibiting customary institutions from adjudicating in land disputes, weakened their authority by providing an alternative forum empowered to override their decisions.

In 1985, the law was amended by the Local Courts (Amendment) Act 1985. The amending Act made referral to customary institutions, denoted as "chiefs", a prerequisite for lodging a customary

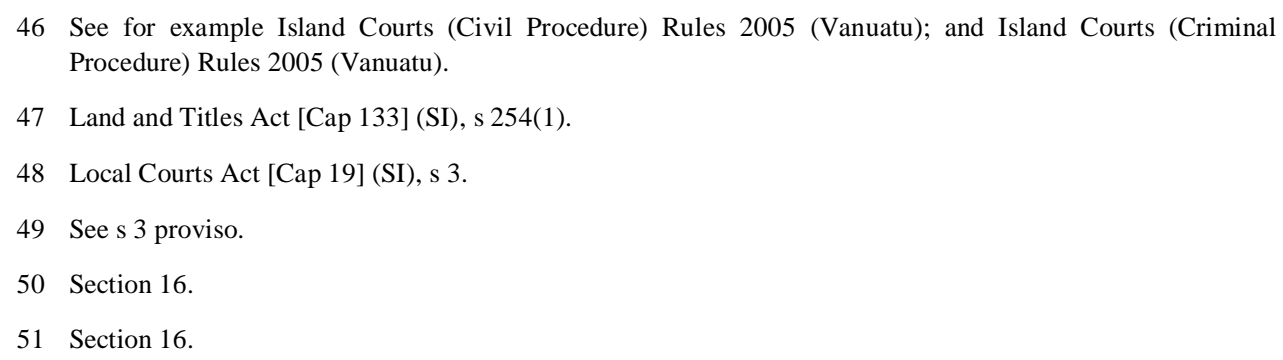


land claim with the Local Courts. Thus, Local Courts only have power to hear customary land disputes where:

- the dispute has first been referred to the chiefs;

- $\quad$ all traditional means of resolving the dispute have been exhausted; and

- the chiefs have made no decision wholly acceptable to both parties. ${ }^{52}$

"Chiefs" are defined in the Act as meaning "chiefs or other traditional leaders residing within the locality of the land in dispute and who are recognised as such by both parties to the dispute". ${ }^{53}$ This leaves the determination of who qualifies as a chief to be made in accordance with customary laws, rather than by the state's dictate.

Whilst this landmark piece of legislation returns first instance jurisdiction over customary land disputes to traditional institutions, this does not necessarily equate with deep legal pluralism. The first reason for doubt is raised by the question of whether "chiefs" still exist as a traditional institution throughout Solomon Islands. Changes in customary society and practices have given rise to uncertainties as to the "true" chiefs. ${ }^{54}$ In fact, "chief" is a generic term used commonly to refer to a range of traditional leaders. In some places, the word "elder" is used instead of chief. ${ }^{55}$ Each local language has its own word for chief and, in some areas, things are complicated by the fact that there are different types of chiefs. If chiefly institutions no longer, or have never, existed in an area, the default provision gives jurisdiction to traditional leaders, who may or may not be empowered by customary laws to adjudicate in any particular dispute.

The second reason for doubt is that the chiefs' jurisdiction in customary land matters is not acknowledged to be exclusive, or even concurrent. An unsatisfied party may lodge a claim in the Local Court, taking the case back into the state system. From this perspective, it is arguable that the state is incorporating the chiefs as a bottom rung of the state system. In practice, unsuccessful parties have been unwilling to abide by the chiefs' decisions and almost 100 per cent of cases end up in the Local Court. ${ }^{56}$ As discussed above, Local Courts are not customary and, even if they were, they are not autonomous. Whilst they are endowed with "exclusive jurisdiction in all matters and proceedings of a civil nature affecting or arising in connection with customary land", 57 there is an appeal to the

52 Section $12(1)$

53 Section 11.

54 On a visit to Marovo Lagoon in 2009, the author was asked what the definition of "chiefs" was in the Act, as the chiefs said they wanted to make sure they were acting "legally".

55 Provincial Government Act 1986 (SI), s 30 referred to both "chiefs" and "elders".

56 Matthew Allen and others Justice Delivered Locally: Systems, Challenges, and Innovations in Solomon Islands (World Bank, Washington, 2013) at 19.

57 Land and Titles Act [Cap 133] (SI), s 254(1). 
Customary Land Appeal Court (CLAC), ${ }^{58}$ a state court, established pursuant to legislation. ${ }^{59}$ Moreover, a further appeal lies from the CLAC to the High Court as of right, with a final appeal, with leave, to the Court of Appeal. Appeals are only permitted on the grounds of error of law (which does not include a point of customary law) or failure to comply with any procedural requirement. ${ }^{60}$ However, objections to the presiding chiefs and other spurious procedural objections have been used to divert questions of customary land ownership away from customary institutions. ${ }^{61}$

State courts have also entertained first instance claims based on common law wrongs, even though the case is really about customary land rights. An example is provided by Lauringi v Lagwaeano Sawmilling and Logging Ltd. ${ }^{62}$ In that case, the defendants had been determined to be the "owners"63 of timber rights over the land by the Area Council in a process set out under forestry legislation. ${ }^{64}$ This decision had been confirmed on appeal by the CLAC. The plaintiffs, however, had been determined to be the customary landowners by the Marodo Council of Chiefs and this decision had been confirmed by the Malaita Local Court. The defendants refused to accept the decision of the Local Court and continued with their logging operation. The device used by the Plaintiffs to divert what was essentially a customary land case into the state system was to allege trespass under the common law. The defendants responded to the claim by challenging the jurisdiction of the Marodo Council of Chiefs on the basis that the members did not meet the definition of chiefs in the area where the land was situated. In this case, an interlocutory injunction was granted by the High Court, Lungole-Awich J stating that: 65

From the above facts there is no doubt that both parties have taken lawful steps to assert their rights over the land. The plaintiffs' case cannot be dismissed as baseless at this stage because the Marodo Council of Chiefs [is] said to lack jurisdiction. ... Whether Marodo Council of Chiefs lack[s] jurisdiction is one of the issues to be determined on proper evidence and full submissions on the law at trial.

The last sentence of this quotation illustrates the Court's continued assertion of state jurisdiction in such cases. Insistence that the authority of the customary institution should be determined in a

58 Section 256

59 Section 255(1) empowers the Chief Justice to establish Customary Land Appeal Courts (CLAC) by warrant.

60 Sections 256(3) and 257(4).

61 See for example Muna $v$ Holland [2002] SBHC 109.

62 Lauringi v Lagwaeano Sawmilling and Logging Ltd HC Solomon Islands Civil Case No 131 of 1997, 28 August 1997.

63 For a discussion of the problems surrounding the use of the term "owners", see Jennifer Corrin "Customary Law and the Language of the Common Law" (2008) 37 CLWR 305.

64 Forest Resources and Timber Utilisation Act [Cap 40] (SI).

65 Lauringi v Lagwaeano Sawmilling and Logging Ltd, above n 62. 
common law trial, with "proper evidence and full submissions on the law", detracts from any suggestion that the 1985 legislation establishes deep legal pluralism. In any event, the judgment ignores the fact that the jurisdiction of the Chiefs was no longer an issue, as, on the basis of the defendants' refusal to accept their decision, the plaintiffs had exercised their right to take the matter to the Local Court, which had made its own decision. The proper course for the defendants was to have appealed from that decision to the CLAC, which, although not a traditional body, has at least the virtue of being constituted largely by local people knowledgeable in custom. ${ }^{66}$ In a later interlocutory decision in the High Court case, the same judge reaffirmed the state's power to adjudicate in customary land disputes framed in trespass, stating that it was "now settled that the High Court has original jurisdiction to decide the question of interlocutory injunction order restraining trespass, conversion and other wrongs on or affecting customary land" ${ }^{67}$ In the interim, the Local Court had made a further decision about the land, which favoured the defendants and the plaintiffs had appealed to the CLAC. Interestingly, the High Court, whilst expressing itself as anxious to comply with the provisions of the Land and Titles Act giving exclusive jurisdiction to the Local Courts and refusing to rule on questions of primary ownership and the extent of the area of land in dispute, was still not prepared to remit the whole case to the CLAC. ${ }^{68}$

As discussed above, in order to constitute an example of deep legal pluralism, an adjudicating institution must be constituted by norms of customary law. Where it relies instead on legislation for its authority, as may be the case if the authority of chiefs or traditional leaders to adjudicate can no longer be found in customary laws, this is at best incorporation of norms (which validated the former institutions) into the state system. Further, although concurrent adjudication powers of state and customary institutions can amount to deep legal pluralism, where the state continues to assert power to overrule decisions of customary institutions, this is more akin to incorporation within the state court hierarchy, and is thus better classified as state legal pluralism. Nevertheless, whilst deep legal pluralism cannot be found at the level of norm application, as mentioned above, in relation to lawmaking power it is perhaps implicit in the Local Courts' mandate to "administer the law and custom of Islanders". 69

66 The requirements of appointment to the CLAC are not set out in the Land and Titles Act [Cap 133] (SI) Section 255(2) states: "A customary land appeal court shall consist of a President, Vice-President and not less than three other members of whom at least one shall be a Magistrate, all of whom shall be appointed by the Chief Justice in his discretion for such periods as he shall at the time of appointment specify".

67 Lauringi v Lagwaeano Sawmilling and Logging Ltd, above n 62, citing Simbe v East Choiseul Area Council HC Solomon Islands Civil Case No 33 of 1997, 20 May 1997.

68 Lauringi v Lagwaeano Sawmilling and Logging Ltd HC Solomon Islands Civil Case No 131 of 1997, 16 September 1999.

69 Local Courts Act [Cap 19] (SI), s 16. 


\section{Law-Making and Adjudication Powers}

\section{Customary institutions in Vanuatu}

In Vanuatu, the Custom Land Management Act 2013 was heralded as "a pragmatic response to the lived reality of contemporary legal pluralism" and it was "anticipated that [the Act would] provide for more accessible determinations of land issues at a local village or custom area level". ${ }^{70}$ The Act purports to formalise "the recognition of customary institutions termed 'nakamals' and 'custom area land tribunals' in this Act to determine the rules of custom which form the basis of ownership and use of land in Vanuatu". ${ }^{71}$ The legislation confers a large degree of autonomy on these institutions, and goes some way towards avoiding the issues experienced by chiefs in Solomon Islands by providing that: ${ }^{72}$

The final decisions reached by these customary institutions, when appropriately recorded, become recorded interests in land which are binding in law and are not subject to appeal to, or judicial review by, any Court of law.

However, whilst these provisions appear at first sight to constitute deep legal pluralism, a more detailed examination reveals some grounds for scepticism. The first issue is whether the fora put forward are in fact "customary institutions". "Custom area land tribunals" are certainly not; whilst they may draw on customary laws and practices in their constitution and procedures, this does not amount to deep legal pluralism as they are established under the legislation. ${ }^{73}$ The pedigree of nakamals is more difficult to assess. The Act defines a nakamal as meaning: ${ }^{74}$

[A] customary institution that operates as the seat of governance for a particular area. Members of a nakamal include all men, women and children who come under the governance jurisdiction of that nakamal. A nakamal may be related to a single custom owner group or extended family group, or may be related to a number of custom owner groups or extended family groups living in a village or larger area. The vernacular language terms for the customary institutions termed "nakamal" in this Act are different in different localities across Vanuatu and include Farea in parts of Efate, Gamal in parts of Malekula, Naumel in Motalava and Jaranmoli in parts of Santo ...

This definition appears to be founded on the assumption that, despite the difference in nomenclature, the nakamal is accepted throughout Vanuatu as a "seat of governance". However, there

70 Siobhan McDonnell "New Territory" (5 March 2014) Australian National University $<$ http://pasifika.anu.edu.au>.

71 Custom Land Management Act 2013 (Vanuatu), s 1(1).

72 Section 1(2)

73 As explained in Morse and Woodman, above n 2, at 17.

74 Custom Land Management Act 2013 (Vanuatu), s 2(1). 
is empirical research which casts doubt on this. ${ }^{75}$ For example, in some parts of the country there is evidence to suggest that the nakamal is merely a social gathering place and has no significance for land rights. ${ }^{76}$

The Act has been said to remove "the power from courts and the government to determine who the custom owners are and puts it back under rules of custom". ${ }^{77}$ In fact, unlike the Solomon Islands legislation, which leaves the process to be determined by the chiefs, the Vanuatu Act introduces a number of Western style procedural rules. Whilst it states that the meeting to determine custom owners "must be convened in accordance with the custom of the relevant nakamal and all decisions of the nakamal must be made according to the rules of custom" ${ }^{78}$ it goes on to prescribe the following procedures:

(1) A quorum of at least two-thirds of the adult members of the nakamal must be present at the meeting in order to reach a valid decision. ${ }^{79}$

(2) Where membership of the nakamal exceeds 300, the decision must include at least one-third of the adult members in order to be valid. ${ }^{80}$

(3) Decisions "must be made by consensus of the members of the nakamal in accordance with the custom of the custom area in which the nakamal is situated". ${ }^{81}$

(4) Members of a nakamal include all men, women and children who come under the governance jurisdiction of that nakamal. ${ }^{82}$

(5) Where the nakamal fails to determine ownership within 30 days, the Act "allows for mediation to progress the resolution of land disputes". 83

There is no evidence to suggest that customary laws require any nakamal to have a specific quorum or that consensus or, failing that, mediation is a common method of decision making. Further, given the patriarchal nature of Vanuatu societies, it seems unlikely that giving women and children a say in the decision making process would be in accord with customary rules and practices throughout

75 Sue Farran "Customs, Laws and Traditions: Bright Lines or Grey Areas?" in Alexis Albarian and Olivier Morétau (eds) Le droit comparé et ... Comparative Law and ... (Presses Universitaires d'Aix-Marseille, Marseille, 2016) 65.

76 Farran, above n 75, at 70-73.

77 McDonnell, above n 70, citing Minister Regenvanu.

78 Custom Land Management Act 2013 (Vanuatu), s 17(3).

79 Section 25(1).

80 Section 25(2).

81 Section 25(5).

82 Section 2(1).

83 Sections 1(3) and 21(2) and pt 5. 
the country. Accordingly, these provisions seem to conflict with the definition set out above, which states that "nakamal means a customary institution that operates as the seat of governance for a particular area". ${ }^{84}$ Further, whilst some degree of finality is conferred, the Act goes on to provide for state institutions, in the form of Island Courts (Land) to review the decisions of a nakamal or custom area land tribunal on the grounds of an incorrect composition, improper process or fraud. ${ }^{85}$ This provision reinforces the state regulation of the adjudication process in the nakamal and tribunal.

In conclusion, the customary area land tribunals are not customary institutions, and there is doubt as to the authenticity of nakamals as seats of land dispute resolution in all areas of the country. The degree of procedural changes wreaked by the Act and the control exercised through the power of review by the state casts doubt on the level of acknowledgment accorded to these "traditional institutions". For these reasons, the claim that the Custom Land Management Act 2013 constitutes a deep engagement with pluralism appears overstated. Rather than endorsement of customary institutions, the Act has created a statutory hybrid, which draws on customary institutions, but dictates the terms of their operation to such an extent that they can no longer be labelled customary. On the other hand, as in Solomon Islands, deep legal pluralism seems to exist in respect of law-making powers, as non-state rules of custom are implicitly acknowledged as forming the basis of ownership and use of land, echoing express acknowledgement in the Constitution. ${ }^{86}$

\section{Village fono}

In Samoa, the Village Fono Act 1990 recognises the "power and authority" of the long existing village fono (councils). ${ }^{87}$ They consist of the assembly of the Alii ma Faipule or matais (chiefly heads of families or aiga) from the particular village, "meeting in accordance with the custom of the village". ${ }^{88}$ The Act states that the "past and future exercise of power and authority by a Village Fono with respect to the affairs of its village in accordance with the custom and usage of that village is hereby validated and empowered". ${ }^{9}$ It also confers additional powers relating to hygiene and economic development, if those powers are not already held by the fono, providing: ${ }^{90}$

(1) A Village Fono shall in respect to its village have the powers set out in subsection (2) even if the powers may not in a particular village form part of its custom and usage.

84 Section 2(1).

85 Section 45.

86 Constitution of Vanuatu 1980, s 74.

87 Village Fono Act 1990 (Samoa), long title.

88 Section 2.

89 Section 3(3).

90 Section 5(1). 
(2) The powers referred to in subsection (1) are:

(a) the power to make rules for the maintenance of hygiene in the village; and

(b) the power to make rules governing the development and use of village land for the economic betterment of the village ...

With regard to adjudication, in addition to the exercise of its existing "power and authority" the village fono is specifically permitted to punish a person guilty of "village misconduct", that is, failing to obey any of the rules made under the law-making powers granted or preserved by the Act. ${ }^{91}$

Whilst the recognition of the village fono's power to make laws and to adjudicate appears to be an example of deep legal pluralism, the language is troublesome. The Act uses the phrase "validated and empowered" in both the long title and the substantive provisions, which could be taken to suggest that the state is asserting that it has conferred powers on the village fono. Morse and Woodman consider that any measure of acknowledgment of the power of non-state institutions to perform legal functions, including what they refer to as "acknowledgment by conferment of powers", amounts to deep legal pluralism. ${ }^{92}$ However, if the state's conferment carries with it an assertion of the power to withdraw, amend or override non-state powers, arguably this would maintain the state monopoly of legal authority and thus qualify only as state legal pluralism. This makes it important to look more closely at the context in which the phrase "validated and empowered" is used. In fact, the Act does not persist with the fiction that the power of the fono has been bestowed. It is clear from the definition of "village fono" and the heading of s 3 ("Village Fono continued") that an existing body is being referred to. The Act also makes provision in terms of "past and future exercise of power" which is more akin to confirmation of an existing capacity than to conferral. ${ }^{93}$ Further, the Act makes it clear when conferring specific powers "relating to hygiene and economic development" that this is in addition to the fono's existing powers, which "form part of its custom and usage". 94

In relation to adjudication, the legislation puts some fetters on the customary powers of the village fono. With regard to jurisdiction, this is limited to persons ordinarily resident in the village on customary land. ${ }^{95}$ Further, in practice, state courts have interpreted the Act as confining the village fono's powers of punishment. The Act provides that powers of punishment are "deemed to include": fines in money, mats, animals, food or a combination of any of these things; and work on village

91 Section 5(3).

92 Morse and Woodman, above $\mathrm{n} 2$, at 18 and 20.

93 Village Fono Act 1990 (Samoa), section 3(3).

94 Section 5 .

95 Section 9. 
land. ${ }^{96}$ It has been argued that this implicitly prohibits a fono from imposing other sanctions. ${ }^{97}$ This is in spite of the fact that the section states that these deemed powers include the village fono's powers "to impose punishment under the custom and usage of its village". 98

This debate about the extent of the powers of the village fono's has occurred in the context of the penalty of banishment. Over a period of 15 years, since the Act was passed, Samoan courts have been called on to rule on challenges to this customary penalty based on a conflict with constitutionally enshrined human rights. ${ }^{99}$ Originally, state courts were prepared to support the village fono, ${ }^{100}$ except where banishment conflicted with the right to freedom of religion. ${ }^{101}$ However, more recently, state courts have taken a more restrictive approach, culminating in a judgment preventing the village fono from making such an order. In Mauga v Leituala, the Court of Appeal stated that only the Land and Titles Court (a forum established by the state) ${ }^{102}$ was empowered to impose a banishment order. ${ }^{103}$ That decision has recently been re-confirmed by the Court of Appeal in Punitia v Tutuila. ${ }^{104}$ The Village Fono Amendment Act 2017, which has recently come into force, reconfirms the power to banish, ${ }^{105}$ but subject to certain procedural safeguards. ${ }^{106}$ The Act also encourages the village fono to record its misconduct inquiries in writing and gives the option to register village rules. ${ }^{107}$

The Village Fono Act also encroaches on the customary institution by permitting appeals as of right to the Land and Titles Court. ${ }^{108}$ However, whilst this is a statutory court, it does not follow the

96 Section 6.

97 Guy Powles "Common Law at Bay" (1997) 21 JPacS 61 at 72-73.

98 Village Fono Act 1990 (Samoa), section 6.

99 Ututa'alega v Iulio Land and Titles Court Samoa, 19 March 1987; Ta'amale v Attorney-General CA Samoa CA2/95B, 18 August 1995; and Tuivaiti v Sila [1980-1993] WSLR 17 (SC).

100 Ututa'alega v Iulio, above n 99; and Ta'amale v Attorney-General, above n 99, at 18.

101 Tuivaiti v Sila, above n 99; Sefo v Attorney-General SC Samoa, 12 July 2000; and Lafaialii v Attorney-General SC Samoa, 24 April 2003.

102 Land and Titles Act 1981 (Samoa), s 25(1) which continued the Court originally established by the Samoan Land and Titles Protection Ordinance 1934 (Samoa), s 34 (repealed).

103 Mauga v Leituala CA Samoa, March 2005.

104 Punitia v Tutuila CA Samoa CA11/12, 31 January 2014.

105 Village Fono Amendment Act 2017 (Samoa), s 7.

106 Section 7.

107 Sections 4-6.

108 Village Fono Act 1990 (Samoa), s 11. 
common law model, being constituted by Samoan judges, who must be matai, and assessors. ${ }^{109}$ The law to be applied is custom and usage, although the Court must also apply any relevant statute law. ${ }^{110}$ Legal practitioners have no right of audience before the Land and Titles Court, ${ }^{111}$ and procedure is inquisitorial, rather than adversarial. ${ }^{112}$ Proceedings are normally conducted in "such manner as [the Court] considers most consistent with Samoan custom and usage and natural justice and convenience". ${ }^{113}$ Moreover, the Land and Titles Court cannot substitute its own decision for that of the fono; it may refer a matter back to the fono to reconsider and, in this case, may not entertain a second appeal after the fono has reconsidered the matter. ${ }^{114}$ Moreover, although there is an internal appeal process to the appellate division, there is no appeal to the common law courts on the merits. ${ }^{115}$ The Supreme Court "retains [only] a supervisory jurisdiction in relation to alleged infringements of the Constitution and, to that extent, to review decisions of the Land and Titles Court". ${ }^{116}$

In spite of some encroachment, on balance it appears that the Act is an acknowledgement of existing, legitimate powers. Despite the fact that the Act purports to confer additional powers if the village fono in question does not already possess them, ${ }^{117}$ the village fono does not rely on the state for its authority either to make laws or to adjudicate on them. Whilst there is an appeal to a state "customary" court, the village fono governs its own procedures and the appellate body may not impose its own decision for that of the fono. Most importantly, within Samoa, it is still regarded as a legitimate, traditional institution, ${ }^{118}$ irrespective of any statutory endorsement, and thus it can withstand scrutiny as an example of deep legal pluralism.

109 Land and Titles Act 1981 (Samoa), s 28.

110 Section 37.

111 Section 92 .

112 Provision is made for rules of court to be made and, in their absence, for the rules of the Supreme Court to apply, but this has not been the practice: Jennifer Corrin "Resolving Land Disputes in Samoa" in Australian Agency for International Development Making Land Work: Volume two (AusAID, Canberra, 2008) 199 at 210 .

113 Land and Titles Act 1981 (Samoa), s 47(5).

114 Village Fono Act 1990 (Samoa), s 11.

115 Land and Titles Act 1981 (Samoa), ss 78-79.

116 Sefo v Attorney-General, above n 101. See also Malifa v President Land and Titles Court SC Samoa CA7/14, 24 September 2014.

117 Village Fono Act 1990 (Samoa), s 5.

118 Samoa Law Reform Commission Village Fono Act 1990 Report (09/12, July 2012) at [1.2] and [1.3]. 


\section{CONCLUSION}

Where the state recognises customary institutions through legislation, the level of encroachment or interference required before the institution in question is no longer customary is a question of degree. Whilst there is an argument that the very process of bringing a customary institution within a formal Act of Parliament may be regarded as converting it to a state body, this does not appear to be the case in the Pacific. However, from the above analysis, it appears that, other than the village fono, the instances discussed do not constitute examples of deep legal pluralism, except in so far as there is an implied acknowledgment of the law-making powers of customary institutions.

This is not to say that the legislation discussed is not valuable. To the contrary, all the Acts discussed constitute valiant attempts to make Pacific legal systems more responsive to the cultural climate. Whilst more akin to a common law hybrid than a model for deep legal pluralism, Papua New Guinea's Underlying Law Act is a unique attempt to accommodate, rather than marginalise, customary laws made by customary institutions. Similarly, both the Local Courts (Amendment) Act 1985 in Solomon Islands and the Customary Land Management Act in Vanuatu respond to the need to have disputes about customary land determined in customary fora rather than common law courts. Whilst the degree of recognition given by these Acts to the power of non-state institutions to apply customary laws may not amount to deep legal pluralism, there is implicit recognition of their law-making powers.

In all cases, the legislation is a welcome attempt to respond to the constitutional mandates to accommodate custom in state legal systems. Forty years after the Papua New Guinea Law Reform Commission highlighted the need to "get down to the business of developing a legal system that [will] take far greater account of the customs and the perceptions of the people than was taken before Independence", action is well overdue. ${ }^{119}$

119 Law Reform Commission of Papua New Guinea Declaration and Development of the Underlying Law (Working Paper No 4, 1976) at 9-10. 